\title{
C)imos
}

JIIFAD

\section{Debating Shifting Cultivation in the Eastern Himalayas Farmers' Innovations as Lessons for Policy}

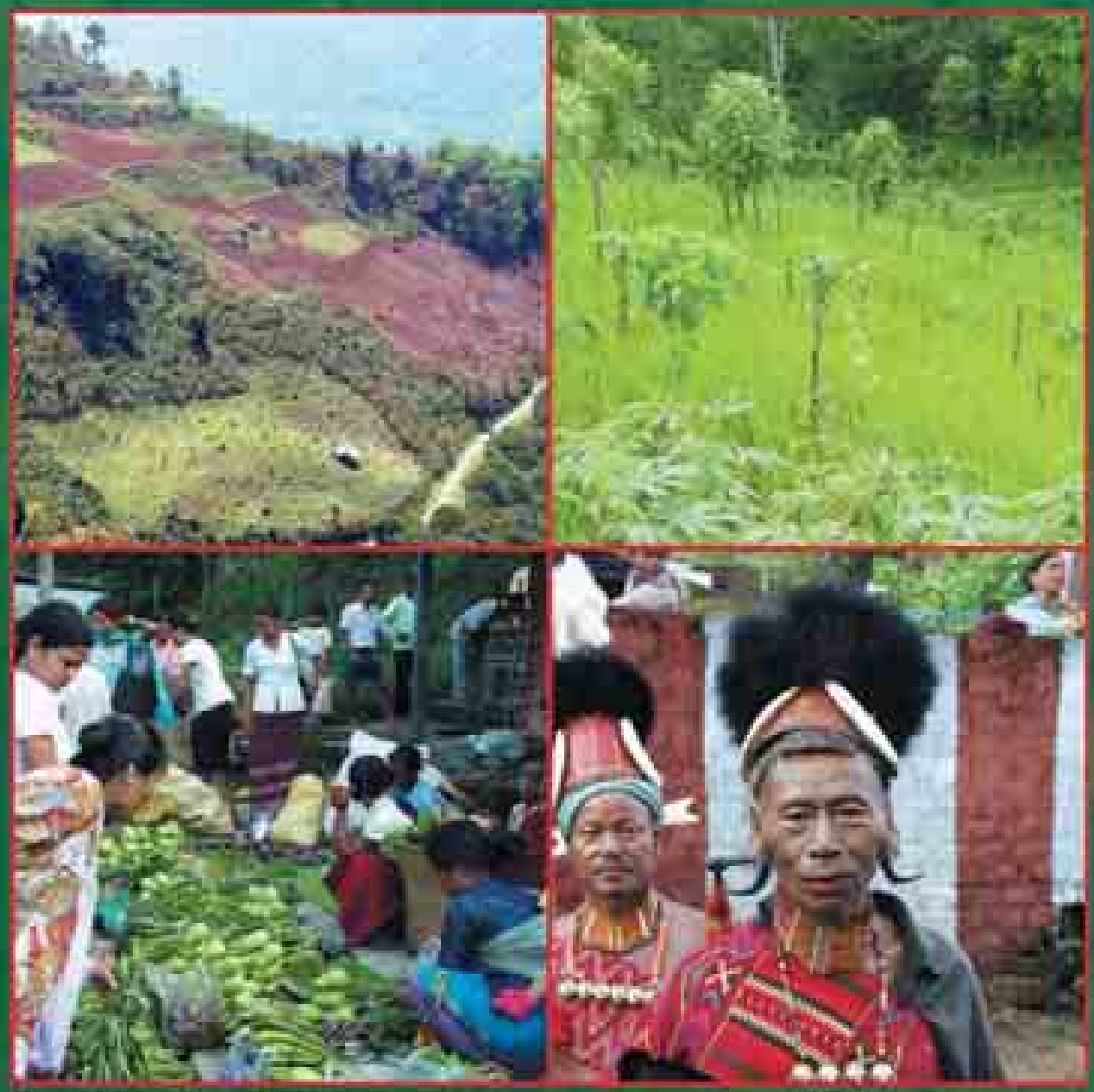




\section{About the Organisations}

The International Centre for Integrated Mountain Development (ICIMOD) is an independent 'Mountain Learning and Knowledge Centre' serving the eight countries of the Hindu Kush-Himalayas - Afghanistan - , Bangladesh $\square$,

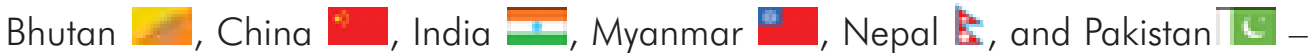
and the global mountain community. Founded in 1983, ICIMOD is based in Kathmandu, Nepal, and brings together a partnership of regional member countries, partner institutions, and donors with a commitment for development action to secure a better future for the people and environment of the extended Himalayan region. ICIMOD's activities are supported by its core programme donors: the Governments of Austria, Denmark, Germany, Netherlands, Norway, Switzerland, and its regional member countries, along with over thirty project cofinancing donors. The primary objective of the Centre is to promote the development of an economically and environmentally sound mountain ecosystem and to improve the living standards of mountain populations.

The International Fund for Agricultural Development (IFAD) is a specialized agency of the United Nations dedicated to enabling rural poor people to overcome poverty. It began operations in 1978 in response to a resolution adopted by the 1974 World Food Conference calling for the establishment of an international fund to finance agricultural development programmes and projects primarily in developing countries. IFAD provides financing and mobilizes additional resources for programmes and projects that promote the economic advancement of rural poor people. The organization's activities are guided by three strategic objectives: to strengthen the capacity of rural poor people and their organizations; to improve equitable access to productive natural resources and technologies; and to increase rural poor people's access to financial services and markets. 


\title{
Debating Shifting Cultivation in the Eastern Himalayas
} Farmers' Innovations as Lessons for Policy

\author{
Compiled by \\ Elisabeth Kerkhoff \\ and \\ Eklabya Sharma
}

International Centre for Integrated Mountain Development (ICIMOD) 


\section{Copyright (C) 2006}

International Centre for Integrated Mountain Development

All rights reserved

\section{Published by}

International Centre for Integrated Mountain Development (ICIMOD)

G.P.O. Box 3226

Kathmandu, Nepal

\section{ISBN-10 92-9115-009-6}

ISBN-13 978-92-9115-009-0

\section{Cover Photos}

Background: Shifting cultivation landscape (E. Kerkhoff)

Front inset, clockwise from top left:

- Forest and shrub fallows are part of the farming system (E. Kerkhoff)

- Agrobiodiversity in shifting cultivation (E. Kerkhoff)

- Customary authorities, like these Konyak elders, are the main natural resource managers (S. Chakraborty)

- Marketing of shifting cultivation produce (S. Chakraborty)

Back inset: Policy makers, researchers, development workers, and farmers from Bangladesh, Bhutan, India, Myanmar, and Nepal at the Shillong Workshop

\section{Separator Photos}

Section 1: Forest and shrub fallows are part of the farming system in Bhutan (E. Kerkhoff)

Section 2: Pollarded alders are a very useful innovation in Manipur, India (S. Chakraborty)

Section 3: Nepali policy makers, officials, and researchers take a fresh look at shifting cultivation (E. Kerkhoff)

Annex: Participants at the Shillong Workshop

\section{Editorial Team}

A. Beatrice Murray (Senior Editor), Dharma R. Maharjan (Technical Support and Layout), Asha Kaji Thaku (Cartographer/Artist)

\section{Printed and bound in Nepal by}

Quality Printers Pvt. Ltd.

Kathmandu

\section{Reproduction}

This publication may be reproduced in whole or in part and in any form for educational or non-profit purposes without special permission from the copyright holder, provided acknowledgement of the source is made. ICIMOD would appreciate receiving a copy of any publication that uses this publication as a source. No use of this publication may be made for resale or for any other commercial purpose whatsoever without prior permission in writing from ICIMOD.

\section{Note}

The views and interpretations in this publication are those of the contributors. They are not necessarily attributable to ICIMOD and do not imply the expression of any opinion concerning the legal status of any country, territory, city or area of its authorities, or concerning the delimitation of its frontiers or boundaries, or the endorsement of any product. 


\section{Foreword}

It might indeed be paradoxical to imagine that the basic philosophy of shifting cultivation has been 'to create forests and not to destroy forests', for without forests the next jhum cannot be cultivated.

Shifting cultivation is an old topic, and there is plenty of conventional wisdom, set opinions, and policies that have been in place for a long time. It has been generally and widely considered that shifting cultivation is always bad from both environmental and socioeconomic perspectives. Or, if it wasn't all considered bad, it was fine when there was a long rotation, but now the rotation has become too short, so therefore shifting cultivation is bad. Thus the only wise policy is to stop shifting cultivation and look for new alternatives.

This makes us ask, why have these new alternatives not been working that well? Are the hundreds of millions of people dependent, at least partly, on shifting cultivation in Asia wrong in the way they cultivate their land?

We have realised the need for new research, re-appraisal of old research, a need for us to listen to the new voices and old wisdom of indigenous people, a need to incorporate new values and understanding that have been coming in globally. Through the work of ICIMOD, we have come to realise that there is a mountain perspective which is different from the plains' perspective. It's one that values a completely different approach to sloping land and the many different products that come from that kind of diversity. This has led us to new insights, new data, new energy, new sympathies and new questions.

We are aware that there are many negative examples of shifting cultivation, but have to ask: do they present a scientifically accurate picture? Too often, shifting cultivation gets compared to natural forests, but if compared to either settled agriculture on these same sloping lands or mono crop forest plantations - as it should be, for these are policy alternatives generally recommended in all five countries in this study - shifting cultivation is often - but not always - the better alternative. The potential for growth and rural transformation by people themselves is high, building on their own knowledge, own institutions and social and cultural capital.

So how have we gone wrong, or partly wrong, if we agree that we have? For one thing, I would suggest that the wrong label has led to the wrong focus. Slash-andburn and shifting cultivation are very negative terms. They give the wrong focus, the slashing, burning, shifting, the image of fire. If we change our label from slash-andburn to rotational agroforestry or agroforestry with a burn cycle, or a form of forest gardening, then we start to use positive words that focus on the growth cycle rather 
than the cutting cycle. As studies show, farmers spend many more years growing trees and crops than burning them - protecting soil, restoring nutrients, fallowing and resting. And in most land allocation regimes under shifting cultivation, issues of equity and poverty are often better addressed than in the alternatives.

Why is it urgent to re-examine and revise our policies? There are 10 million hectares in South Asia under rotational agroforestry or agroforestry with a burn cycle. It is the dominant land use in vast areas in North East India, the Chittagong Hill Tracts of Bangladesh, Eastern Bhutan, hilly Myanmar, Southwest China and parts of Nepal. Most shifting cultivators of the eastern Himalaya fall into the 14-38\% of very poor who live on less than 1 US dollar a day.

Traditional shifting cultivation faces huge obstacles both from development and from policies. Shifting cultivators have been given little space for support and for innovation within their cultivation, and yet we know that the attempts to completely change this system and replace it with entirely different agricultural and horticultural systems have mostly been unsuccessful. Therefore, we need positive alternatives.

The 'Farmers' Innovations in Shifting Cultivation' initiative was designed by ICIMOD and its partners from five countries of the eastern Himalayas, including Bangladesh, Bhutan, India, Myanmar and Nepal, with support from the International Fund for Agricultural Development (IFAD). It has brought together experts from our regional member countries who have been doing path-breaking research, advocacy, and development implementation. There is a strong working group debating the issues, a network of jhumias who formed electronically, and there have been working group meetings and policy fora in India and Nepal. What has come out of this is that there are commonalities throughout the region, there are real policy options already available to be debated and considered, and that can be up-scaled.

The results provoke us to challenge our old ideas, think new thoughts, and do new actions. Not because the old thoughts were wrong, everyone can cite real examples of degradation from unsustainable shifting cultivation in distorted form and these are true. But because maybe they are only partly true when distorted; there is a need to examine the real balance in light of experience and data; a need to recognise traditional knowledge; a need to support traditional social security and equity for the poor; a need to have a clear path for real bottom-up development with a facilitative government; a need to learn from innovations throughout the region; and a need to galvanise rural transformation.

This policy document is meant to lead us to new policy dialogues, and help us to collectively challenge the exclusively negative picture that has so far been prevalent. It reflects a shared vision as well as policy options that are both realistic and actionable at national and other levels. The main conclusion is that the common negative perception on shifting cultivation is often misplaced. Shifting cultivation - if properly practised - is actually a 'good practice' system for productively using hill and mountain land, while ensuring conservation of forest, soil, and water resources. 
The findings are that farmers are actively developing viable solutions within shifting cultivation or they are modifying their practices in the light of opportunities.

For all these reasons this document deliberately takes a provocatively positive approach. The chapter headings are designed to challenge conventional wisdom and stimulate new approaches.

Now at the time of publication of this document, some spin-offs of this initiative can be seen in the form of positive developments. At the policy level, several partners have actively advocated our common policy findings, including the Shillong Declaration and accompanying recommendations, by participating at relevant discussion fora, and organising workshops. At community-level, regional-level networking has enabled the exchange and implementation of options for local-level governments to learn from farmers and develop shifting cultivation together.

\author{
J. Gabriel Campbell \\ Director General \\ ICIMOD
}




\section{Contributors}

Many people have worked on different aspects of this study and the publication. The main contributors to the study and compilation of results are listed below.

Compilation: Elisabeth Kerkhoff; Eklabya Sharma

Coordination: Atsuko Toda; C.N. Anil

Core team and working group: C.N. Anil, Imtienla Ao, Malcolm Cairns, J. Gabriel Campbell, Goutam Kumar Chakma, Sanat K. Chakraborty, Dhrupad Choudhury, Vincent Darlong, Julian Gonsalves, Pema Gyamtsho, Amba Jamir, Narpat S. Jodha, Keshav Kanel, Elisabeth Kerkhoff, U Thint Lwin, A. Beatrice Murray, P. S.

Ramakrishnan, Golam Rasul, Bimal Raj Regmi, Eklabya Sharma, Mamata Shrestha, Binay Singh, Karma Tashi, Atsuko Toda, Raj Verma, Pelzang Wangchuk

\section{Country case study teams}

Bangladesh focal team: Sudibya Kanti Khisa, M. Khairul Alam, Abdul Gafur, Mohammed Mohiuddin, Golam Rasul, Mohammad Zashimuddin

Bhutan focal team: Pelzang Wangchuk, Karma Tashi

India focal team: Amba Jamir, Dhrupad Choudhury, Vincent T. Darlong, Vengota Nakaro, Sangita Roy, Loushambam Jitendrao Singh, Brajesh K. Tiwari, Qhutovi Wotsa, K. Showuba Yim

Myanmar focal team: Mya Thwin, Dietrich Schmidt-Vogt, Myint Thein

Nepal focal team: Bimal Raj Regmi, Kamal P. Aryal, Anil Subedi, B. B. Tamang

Publications team: A. Beatrice Murray, Dharma Ratna Maharjan, Asha K.Thaku

The activities were made possible through the support of the International Fund for Agricultural Development (IFAD), with additional contributions from the International Centre for Integrated Mountain Development (ICIMOD), Netherlands Ministry of Foreign Affairs, Directorate-General for International Cooperation (DGIS), and German Technical Cooperation (GTZ).

And finally, none of this would have been possible without the support and active cooperation of the many farmers in the eastern Himalayas who continue to practise and adapt a way of life developed by their forefathers and who shared their experiences so generously with the country teams. 


\section{Executive Summary}

In the eastern Himalayas, shifting cultivation is the most prominent farming system, providing a way of life for a large number of ethnic minorities and other poor and marginalised upland communities. The policy approach to deal with shifting cultivation is common across Bangladesh, Bhutan, India, Nepal and Myanmar, the countries in this study, and aims to replace it with permanent forms of land use. The current problems related to shifting cultivation, however, are found to be often as much a result of counterproductive policies as of inappropriate land use practices. Therefore, there is a need across the region for new, more effective and socially more acceptable policy options that help to improve shifting cultivation, rather than replace it.

The research presented here identifies farmers' traditional practices and more recent indigenous innovations that contribute to the benefits this farming system has to offer. These benefits accrue both to the practitioners and to other stakeholders, including national governments. Shifting cultivation, and the farmers' innovations in particular, were found to contribute to forest cover and biodiversity conservation, while at the same time maintaining agricultural and forest productivity. Commercial niche products and organic farming contribute to economic development that is adjusted to mountain circumstances and builds on existing potential. The local institutions developed by shifting cultivation communities were found to be relatively strong, and they enhance social security and cultural integrity. Development approaches that build on these existing potentials and capacity are likely to be more achievable and acceptable to the farmers concerned.

Realising this potential, and the need for policy change across region, the participants of the 'Shifting Cultivation Regional Policy Dialogue Workshop for the eastern Himalayas', held in October 2004 in Shillong, India, adopted the Shillong Declaration and formulated concrete policy recommendations based on the research findings of this initiative. The participants included representatives of government agencies, farmers, international bodies, non-government organisations, academia, science and research institutions, local institutions, international donors and development assistance agencies, the private sector, and other professionals. They recommended policy makers to reexamine the policies in place, to remove explicit policies and policy instruments that discourage shifting cultivation, and to strengthen the implementation of existing beneficial policies. They also recommended that they address issues of land tenure security, research, and extension and their impact on traditional shifting cultivation practices; market development and commercialisation of niche products of shifting cultivation; strengthening and capacity building of customary institutions; credit policies in situations where common property regimes apply; and coordination among the different government agencies that have responsibilities for aspects of shifting cultivation. 
Foreword

Contributors

Executive Summary

\section{Part One: Introduction}

Chapter 1 - Current Understanding of Shifting Cultivation 3

Introduction 3

Shifting Cultivation - Rotational Agroforestry in Practice 3

The Need for New Policies 4

Implications for Biodiversity 6

Marginalisation of Indigenous Peoples $\quad 7$

Recent Developments $\quad 7$

The ICIMOD Initiative 8

Organisation of the Book 12

\section{Part Two: Farmers' Innovations in Shifting Cultivation}

Chapter 2 - "Shifting Cultivators Conserve More Forests on Their Land than any Other Farmers, and Make It Productive at the Same Time"

Forest Fallows and Their Importance 15

How Do Shifting Cultivators Manage and Enhance Forest Fallows? 18

What Are the Opportunities and Constraints for Fallow

Management in the Current Situation? 26

Policy Points $\quad 29$

Chapter 3 - "Biodiversity Conservation is Favoured in the Forest and Farm Management Practised in Shifting Cultivation"'

Biodiversity in the Eastern Himalayas

How Does Shifting Cultivation Benefit Biodiversity Conservation?

What Are the Opportunities and Constraints for Biodiversity

Conservation in the Current Situation? 
Chapter 4 - "Shifting Cultivation is a Storehouse of Species of Commercial Value and Innovative Organic Farming Practices"

Commercial Mountain Products and Organic Farming

Commercial Crops and Organic Farming Techniques

What Are the Opportunities and Constraints for Organic and

Commercial Farming in the Current Situation?

Policy Points

Chapter 5 - "Social Security is One of the Main Functions of Local Institutions of Shifting Cultivators"

The Importance of Strong Local Level Institutions and

Customary Tenurial Arrangements

How Do Shifting Cultivators Manage and Enhance Local

Institutions and Customary Rules?

What Are the Opportunities and Constraints for Local

Institutions to Function in the Current Situation?

Policy Points

\section{Part Three: Policy Issues and Recommendations}

\section{Chapter 6 - Regional Policy Dialogue}

Introduction

Policy Issues and Recommendations of the Regional Policy

Dialogue Workshop

The Shillong Declaration on Shifting Cultivation in the Eastern

Himalayas

Chapter 7 - Outlook

81

References

83

\section{Annex}

